\title{
Az Iszlám Állam tevékenysége Törökországban a Kalifátus idején
}

\begin{abstract}
Az elemzés az Iszlám Állam tevékenységét, annak körülményeit mutatja be egy geopolitikai szempontból is kiemelt fontosságú országban. Az elmúlt években megjelent elemzések egyre több információval szolgálnak a terrorszervezet müködésével és korábbi hálózatépitési módszereivel kapcsolatban, amely befolyásolta a közel-keleti régió biztonságát. A Kalifátus idején a biztonsági helyzet romlásával elkerülhetetlenné vált, hogy a török vezetés megfelelő válaszlépéseket és intézkedéseket foganatosítson az ország nemzetbiztonságát is veszélyeztető fenyegetésekkel szemben.
\end{abstract}

Kulcsszavak: Törökország, Iszlám Állam, terrorizmus, geopolitika

\begin{abstract}
Málnássy András: Activities of the Islamic State in Turkey during the Caliphate
The current analysis offers an overview of the activities of the Islamic State and its circumstances in an important country in terms of geopolitics. Analyses published in the last years provide more and more details on the operation of the terrorist organisation and its network, which has had a significant impact on the security of the Middle East region. According to the deterioration of the security situation during the Caliphate, it became inevitable for the Turkish Government to take appropriate action and measures to address the threats affecting the country's national security.
\end{abstract}

Keywords: Turkey, Islamic State, terrorism, geopolitics

Az Iszlám Állam elöretörése és a szíriai polgárháború mélyülése jelentős biztonsági kihívásokat támasztott a környező országok, köztük Törökország számára. A szíriai és az iraki biztonsági helyzet romlásával a kis-ázsiai országban megsokasodtak az öngyilkos merényletek, a robbantásos és a kézifegyverekkel elkövetett terrorcselekmények. Ezen támadások összefüggésben lehetnek azzal, hogy az országból korábban, különböző dzsihádista csoportokhoz való csatlakozás szándékával jelentős számban utaztak ki az úgynevezett külföldi terrorista harcosok, ${ }^{1}$ akik a konfliktusövezetekben harci tapasztalatot szereztek, tovább radikalizálódtak, majd pedig a korábbi kapcsolataikat fenntartva időközben visszatértek szülöföldjükre. A szíriai harcokban török állampolgárok bizonyítottan részt vettek több radikális dzsihádista szervezet oldalán is, úgymint az Iszlám Állam, a Dzsabat Fatah al-Sham ${ }^{2}$ vagy a szalafista Ahrar al-Sham. ${ }^{3}$

\footnotetext{
1 A kifejezés angol megnevezése: foreign terrorist fighters. Külföldi harcosnak tekintem egy polgárháború kapcsán azt a helyi állampolgársággal nem rendelkező személyt, aki önszántából csatlakozik az egyik harcoló csoporthoz.

2 A szervezet korábbi neve al-Nuszra Front.

3 Aaron Stein: Islamic State Network in Turkey, Recruitment for the Caliphate, [online], 2016. 10. 01. Forrás: Atlanticcouncil.org [2019. 03. 10.]
} 
A Kalifátus terjeszkedésével és katonai sikereivel párhuzamosan megnőtt a török-szír határszakasz forgalma, amely során több dzsihádista harcos juthatott be Törökországba nemzetbiztonsági kockázatot jelentve ezzel az országnak. A török „állomáshelyeket” a radikális harcosok gyakran pihenőhelyként, logisztikai bázisként, búvóhelyként vagy adott esetben toborzó tevékenységük kifejtésére, illetve kiképzésre is használták.

\section{Törökország geopolitikai elhelyezkedése}

A kis-ázsiai ország évszázadok óta Európa történelmének egyik meghatározó, bizonyos értelemben kulcsfontosságú állama. A Török Köztársaság földrajzi helyzeténél fogva régiókat és kontinenseket, a Keletet és a Nyugatot köti össze. Ebből adódóan Törökországot leggyakrabban „hídországként” szokás ábrázolni, amely szerepét és jelentőségét geopolitikai és regionális hatalmi szempontból is felértékeli. Ahmet Davutoğlu szerint Törökországnak sokféle kapcsolódási pontja van, amely alapján európai és ázsiai egyszerre, de a Földközitenger keleti medencéjén keresztül az afrikai kontinenshez is kapcsolódik. Az ország két kontinens, Európa és Ázsia határán fekszik, történelmi népvándorlások és hadviselések útvonalán. ${ }^{4}$ Két szoros - a Boszporusz és a Dardanellák - birtoklásával ellenőrzi az Égeiés a Fekete-tenger közötti hajóforgalmat. Emellett az ország közelében fekvő stratégia ásványkincslelőhelyek, a Kaszpi-tenger és a Perzsa-öböl térségében található jelentős mennyiségü kőolaj- és földgázkészletek miatt a török állam geopolitikai fontossága is számottevő.

Davutoğlu felfogása szerint a geopolitikai rendszerben Törökország egy központi állam, amely adott esetben rendelkezik azokkal a lehetőségekkel, hogy befolyásolja még a világrend alakulását is. Davutoğlu szerint Törökország nemcsak anatóliai hagyományokkal rendelkezik, hanem közel-keleti ország is egyben, amely felfogás jól jellemzi az országról való gondolkodás irányait. Mindezekből az is következik, hogy a Törökországot szorosan körülvevő területek, mint például Szíria az ország befolyási övezetének tekinthetők. Erre jó példa lehet, hogy 2010-ben a török elnök bejelentette, a környező államokkal (Jordánia, Szíria, Libanon) Schengen mintájára létrehoznak egy övezetet. ${ }^{5}$ Ez is jól mutatja, hogy a Török Köztársaság külpolitikájában új, ambiciózus törekvések jelentek meg az elmúlt években, amelyek célja, hogy Ankara a térség elismert és regionális hatalmává váljon. Erre Ankara központi elhelyezkedése lehetőséget biztosít, ugyanakkor a biztonság szempontjából az úgynevezett $h u b^{6}$-jelleg kihívásokat és kockázatokat is jelent az ország számára.

\section{Az Iszlám Állammal kapcsolatos török (kül)politika}

A terrorszervezettel szembeni török megítélést a térségbeli kurd ambíciók és a szíriai polgárháborúval kapcsolatos érdekek szempontjából érdemes vizsgálni. A polgárháborúba való török beavatkozás egyfelől a Bassár al-Aszad vezette kormány megbuktatását, másfelől

4 Baranyi Tamás Péter - SzÁlkai Kinga (szerk.): Újhold - A török külpolitika útkeresése a 21. század elején, Antall József Tudásközpont, Budapest, 2016, 7. o.

Egeresi Zoltán: Az AKP külpolitikájának pillérei. In: Baranyi Tamás Péter - SzÁLKai Kinga (szerk.): Újhold - A török külpolitika útkeresése a 21. század elején, Antall József Tudásközpont, Budapest, 2016, 121-131. o.

6 A kifejezés az ország központi elhelyezkedésére, „csomópont” jellegére utal, ahol szárazföldi, tengeri útvonalak keresztezik egymást. 
az észak-szíriai kurd autonómia létrejöttének megakadályozását szolgálta. A konfliktus kirobbanását követően Törökország az ellenzéki csoportok elsődleges támogatója lett, például a Szabad Szíriai Hadsereg központját is a kis-ázsiai országban hozták létre. ${ }^{7}$

Az Iszlám Állammal szembeni török fellépés, vagy annak hiánya sok esetben tulajdonképpen az érdekek egyezéséből vagy különbözőségéből következett. Előbbire lehet példa a terrorszervezet észak-szíriai kurdellenes kampánya, amely egybeesett a török érdekekkel. Másfelől viszont az ankarai kormányzat gyanakvását eredményezte, hogy az Iszlám Állam az Aszad-rezsim mellett az ellenzék erőivel is folyamatosan harcban állt, Aleppó térségében pedig azokkal szemben együtt is müködött a kormányerőkkel. ${ }^{8}$ Egy másik szempont lehet a terrorszervezettel kapcsolatos török külpolitikában az is, hogy míg az Igazság és Fejlődés Pártja ${ }^{9}$ áttal képviselt politikai iszlám és Abu Bakr al-Bagdádi radikális dzsihádizmusa tartalmazhat átfedéseket, a gyakorlatban azonban inkább ideológiai versenytársaknak tekinthetők. $^{10}$

Törökország Iszlám Állammal szembeni politikájában 2015-ben lényeges változás következett be, amely elsősorban az országban elkövetett terrorcselekmények számának növekedésének tulajdonítható. Ahogy a terrorszervezet közvetlen fenyegetéssé vált az ország számára, az ankarai kormányzat folyamatosan lépett fel ellene, és egyben a politikai céljai érdekében felhasználta a fenyegetést a PKK-val szembeni katonai műveletek legitimálására. Mivel a kurd erők egyre nagyobb területeket foglaltak el az Iszlám Államtól Észak-Szíriában, ezért a török vezetés a szíriai harcokba való közvetlen beavatkozás mellett döntött és megindította 2016. augusztus 24-én, a hivatalosan az Iszlám Állam ellen irányuló Eufrátesz Pajzsa hadműveletet. A műveletek során a törökök mintegy $2000 \mathrm{~km}^{2}$ nagyságú területet foglaltak el, azonban a további elörehaladásukat az Egyesült Államok és Oroszország fellépése megakadályozta, rávilágítva ezzel Ankara Szíria-politikájának korlátaira. ${ }^{11}$ Meg kell azért itt is jegyezni, hogy a szárazföldi beavatkozást azért alapvetően nem a dzsihádistáktól való félelem, hanem sokkal inkább a kurd törekvések megakadályozása ösztönözte. A török kormányzat Iszlám Államhoz való viszonyulását jelenleg is a fentebb kifejtett két elem, vagyis a szíriai polgárháborúhoz köthető török érdekek és még inkább a kurd törekvésekkel kapcsolatos megfontolások határozzák meg.

\section{Az Iszlám Állam toborzó tevékenysége Törökországban}

A radikális iszlamista szervezetek toborzó tevékenységeinek különböző módszerei ismertek. Hatékony toborzási módszernek tekinthető például a személyes kapcsolatokon alapuló meggyőzés, vagy az olyan tevékenységek, amelyek során a toborzó az adott muszlim

Charles R. Lister: Thr Syrian Jihad. Al-Qaeda, the Islamic State and the Evolution of the Insurgency, C. Hurst \& Co., London, 2015, 97. o.

8 Arany Anett - N. Rózsa Erzsébet - Szalai Máté: Az Iszlám Állam Kalifátusa, Osiris Kiadó, Budapest, 2016, 261. o.

9 Adalet ve Kalkınma Partisi - AKP.

10 Uo.

11 Egeresi Zoltán: Konfliktusok az amerikai-török kapcsolatokban, [online], 2018. 02. 12., 6. o. Forrás: Svkk.uni-nke.hu [2019. 03. 18.] 
közösség tagjaként alkalmazza a „rábeszélés módozatait” olyan személyek körében, akik a társadalom perifériáján helyezkednek el. ${ }^{12}$

Az Iszlám Állam toborzó tevékenysége során hatékonyan használja a különböző közösségi média adta lehetőségeket. A terrorszervezet például török nyelvü propagandatevékenységet is folytatott elsősorban a török társadalom azon szegmensében, amelyek körében népszerü gondolat lehet a Kalifátus létrehozása a Közel-Keleten. Jellemző volt, hogy török dzsihádisták a Facebook- és más közösségimédia-oldalakon népszerüsítették az Iszlám Államot, képeket helyeztek el a Szíriába való utazásukról, összekötve őket a szülővárosukkal és a terrorszervezet propagandájával. ${ }^{13}$ 2013-ban megfigyelhető volt például, hogy több török nyelvü dzsihádista hírforrás elkezdte használni az Iszlám Állam narratíváit. 2015-ben pedig az Iszlám Államhoz köthető al-Hayat Média megkezdte török nyelvü hírfolyamának, a Darul Hilafe-nek a sugárzását, valamint létrehoztak egy online magazint, a Konstantiniyye-t. ${ }^{14}$

\section{Online radikalizáció: Az Iszlám Állam propaganda tevékenysége a Twitteren}

2016-ban a Sidar Global Advisors (SGA) szervezet készített egy kutatást az Iszlám Államhoz köthető dzsihádista tartalmú Twitter-fiókok vonatkozásában. Az elemzés 137 radikális személy fiókját, azok 693533 bejegyzését térképezte fel kulcsszavas kereséssel, az érintett témákat, valamint a geolokációt vizsgálva. Az elemzés megállapítja, hogy a „radikális tweetek" többségét három nagyvárosból, Isztambulból, Ankarából és Izmirből tették közzé. A leggyakrabban használt kifejezések pedig a dzsihád, a hitetlen, valamint a Nuszra voltak, utóbbi utalva az al-Nuszra Front terrorszervezetre. További gyakran használt szavak között szerepelt a Jeruzsálem, a mudzsahedin, illetve a cionista. A Twitter-fiókok közül többet, a felmérés készítésének ideje alatt a szolgáltató felfüggesztett, azonban számos esetben a fióktulajdonos más néven új platformot hozott létre. A vizsgálatok szerint ezek a fiókok fokozottan aktívak voltak olyan időszakokban, amikor egy Iszlám Államhoz köthető terrorcselekményt követtek el. Megállapítást nyert továbbá az is, hogy a radikálisok a Twitter-bejegyzéseiket a propaganda mellett meggyőzésre, vallási tanításra és „hittérítésre" is használták. ${ }^{15}$ A 2017. január 1-jei Reina terrortámadásnál a radikálisok például számos bejegyzést helyeztek el, amelyek fö mondanivalója, retorikája az iszlám által tiltott alkoholfogyasztás, valamint a szórakozóhelyen jelen levő nők helytelen öltözködésének megbüntetése volt. ${ }^{16} \mathrm{~A}$ terrortámadást követően a nyomozás során a török rendőrség 347 közösségimédia-fiókot vizsgált meg gyanús tartalmuk miatt. A hatósági vizsgálatok megállapították, hogy a radikális tartalmak ellen korlátozottak a rendvédelmi szervek lehetőségei,

12 Scott Gerwhr - Sara Daly: Al-Qaida: Terrorist Selection and Recruitment, [online], 2006. 01. 01. Forrás: Rand.org [2019. 02. 21.]

13 S. G. Grimaldi - Selim Koru: Is the Islamic State Trying to Draw Turkey into Syria? [online], 2016. 05. 13. Forrás: Warontherocks.com [2019. 01. 19.].

14 Uo., 2-3.

15 Merve Tahiroglu - Jonathan Schanzer: Islamic State Networks in Turkey, [online], 2017. 03. 29. Forrás: Fdd.org [2019. 03. 15.]

16 Ezgi Basaran: Secular citizens of Turkey have never felt so alone, [online], 2017. 01. 03. Forrás: Washingtonpost.com [2019. 03. 18.] 
ugyanis számos esetben a letiltást követően ugyanaz a személy más felhasználónéven létrehozott új fiókján keresztül folytatta tovább káros tevékenységét. ${ }^{17}$

\section{A Reina szórakozóhely ellen elkövetett terrorcselekmény hátteréről}

A 39 halálos áldozatot és 71 sérültet követelő támadás elkövetőjéről a cselekmény végrehajtása után folyamatosan jelentek meg a különböző információk mind a helyi, mind pedig a nemzetközi sajtóban egyaránt. Az üzbég nemzetiségü Abdulkadir Masharipov vagy ahogyan az Iszlám Állam katonájaként nevezték Mohammed Horaszani 1983-ban látta meg a napvilágot egy kirgizisztáni, többségében üzbégek lakta kisvárosban. Masharipov Üzbegisztánban a Fergana Állami Egyetemen fizika és számítástechnika szakon végzett, négy nyelven: üzbégül, arabul, kínaiul és oroszul beszél. Az üzbég hatóságok információi szerint a férfi 2011 óta volt tagja az Iszlám Állam terrorszervezetnek. ${ }^{18}$

Masharipov letartóztatását követően a török rendőrségnek elmondta, hogy katonai képzésben részesült 2010-ben egy al-Káida kiképzőtáborban Afganisztánban. Később pedig pakisztáni tartózkodása során az Iszlám Államhoz csatlakozott és hüségesküt tett a terrorszervezet emírjének, Abu Bakr al-Bagdádinak.

A vizsgálatok megállapították, hogy Masharipov a terrortámadás előtt egy évvel érkezett a törökországi Konyába. A férfi utazását az Iszlám Államhoz köthető személyek irányították a szíriai Rakkából. A feltételezések szerint ezen személyekkel még a pakisztáni tartózkodása során építhetett ki kapcsolatokat. ${ }^{19}$

\section{A reinai terrortámadás végrehajtása}

Masharipov elmondása szerint 2016. december 25-én a Telegram üzenetküldő szolgáltatáson keresztül utasítást kapott Rakkából, az Iszlám Állam egyik vezetőjétől, egy úgynevezett Abu Shuhadától, hogy az újév napján terrortámadást hajtson végre Isztambulban. A városba való érkezését követően egy számára ismeretlen férfitől egy AK-47 típusú gépkarabélyt, és három gránátot kapott. A fegyvereket Masharipov az általa bérelt lakásban vette át. ${ }^{20}$

A terrorista elsődleges célpontja az isztambuli Taksim tér volt, ahol az újév alkalmából nagy számú ünneplő tömeg szokott megjelenni. Masharipov a térről, azaz a leendő célpontról selfie-videót készített, amelyet Abu Shuhada jóváhagyott. Amikor azonban az üzbég férfi a helyszínre érkezett elvetette a támadás végrehajtását, mivel túlságosan nagy volt a rendőri készültség a közterületen. Ekkor Abu Shuhada egy másik célpont kijelölésére utasította, és így esett a választás a kevésbé biztosított Reina szórakozóhelyre. A terrorista ezt követően taxiba szállt, és a szállásán elrejtett fegyverek felvétele után visszament a szórakozóhelyre, hogy végrehajtsa a támadást. Masharipov először az ajtóban álló rendőrtisz-

17 TAhiroglu-Schanzer: i. $m ., 23$.

18 Göktuğ Sönmez: Reina Saldırısı, Maşaripov ve Orta Asya’da Radikalleşme, [online], 2017. 01. 01. Forrás: Orsam.org.tr [2019. 01.20.]

19 Reina saldırganı Abdulkadir Masharipov’un eşi Zarina Nurullayeva, IŞİD’in kaçırdığı oğlunun bulunmasını istedi, [online], 2017. 02. 04. Forrás: Ulusal.com.tr [2019. 03. 22.]

20 Elif Altın: Son dakika... Reina katliamcısından şok ifadeler! Oğlunun intihar eylemcisi olmasını istemiş, [online], 2017. 02. 11. Forrás: Milliyet.com.tr [2019. 03. 21.] 
tet ölte meg, majd berontott a helyre és tüzet nyitott az ott ünneplő közönségre. A támadást követően a férfi elmenekült a színhelyröl, és csak mintegy két hét múlva fogták el a török rendőrök. A férfi által bérelt szálláshelynél a hatóságok két darab drónt, kézi fegyvereket, SIM-kártyákat és 197 ezer dollár készpénzt találtak. ${ }^{21}$

\section{A Reina-terrortámadást támogató isztambuli csoportok}

A török hatóságok vizsgálatai rávilágítottak, hogy Masharipov tevékenységét Isztambulban egy szélesebb terrorista hálózat támogatta. A támadást követően az üzbég férfi öt különböző menedékházban tartózkodott, és egy szenegáli, egy szomáliai és egy egyiptomi nő, valamint egy iraki férfi segített az elrejtőzésben. A három nőről később kiderült, hogy mindannyian az Iszlám Államhoz tartoznak. Masharipov Isztambul több kerületében is bujkált, úgymint Zincirlikuyu, Basaksehir és Esenyurt. A menedékházat, amelyben Masharipovot letartóztatták egy Muaviye álnevü, az Iszlám Államhoz köthető személy felügyelte. A későbbi vizsgálatok megmutatták, hogy Muaviye több, Isztambulban müködő menedékházat is üzemeltetett. ${ }^{22} \mathrm{~A}$ rendőri intézkedések során további személyeket - köztük az Iszlám Állam emírje (helyi vezetője) - is előállítottak, akikről később beigazolódott, hogy számos esetben a terrorszervezethez köthetö harcosokat bújtattak vagy segítettek. ${ }^{23}$

A török hatóságok vizsgálatai alapján a Reina-terrortámadás elkövetőjét legalább 50 személy támogathatta a terrorcselekményt megelözően, majd azt követően. Az elfogások során letartóztatottak többsége a kaukázusi és a közép-ázsiai régióból érkeztek, és orosz anyanyelvüek voltak. A török rendőrség nyomozása során több mint száz, terroristák bújtatására használt menedékházra bukkantak Isztambulban, amelyek mindegyike az Iszlám Államhoz volt köthetö. ${ }^{24}$

\section{Az Iszlám Állam törökországi hálózata}

Az isztambuli csoport, amely segítette a Reina-terrortámadás elkövetőjét csak egy része volt az országban tevékenykedő Iszlám Államhoz köthető hálózatnak. A terrorszervezet - a különböző statisztikai adatok alapján - mintegy 2200 török tagot toborzott, akik kiutaztak Szíriába, majd egy részük visszatért az országba, egy másik részük pedig elhunyt vagy még továbbra is a konfliktusövezetekben tartózkodik. ${ }^{25}$

A Törökországban tartózkodó, az Iszlám Államhoz köthető terroristák és radikális segítők száma 2015-ben kb. 2000 före volt tehetö. A törökországi hálózatoknak több funkciója is lehetett, többek között toborzási lehetőséget, pénzügyi és logisztikai támogatást

21 Özgür Altuncu - Idris Tiftıkcı: Reina saldırganının evinden çıkan Türkçe not!, [online], 2017. 01. 17. Forrás: Hurriyet.com.tr [2019. 03. 21.]

22 DEAŞ’ın ,kadı'sı Ebu Cihad kod isimli Yasser Mohammed Salem Radown tutuklandı, [online], 2017. 01. 25. Forrás: Haberturk.com [2019. 03. 21.]

23 DEAŞ’ın ,kadı́sı Yasser Mohammed Salem Radown tutuklandı, [online], 2017. 01. 25. Forrás: Cnnturk.com [2019. 03. 22.]

24 Ahmet S. Yayla: The Reina Nightclub Attack and the Islamic State Threat to Turkey, [online] 2017. 03. 01. Forrás: Ctc. usma.edu [2019. 03. 20.]

25 The Jihadi Threat: ISIS, Al Qaeda and Beyond, [online], 2016. 12. 12. Forrás: Usip.org [2019. 04. 04.] 
nyújthattak az Iszlám Állam tevékenységéhez, valamint szerteágazó menekülő útvonalakat és menedékhelyeket biztosíthattak a szervezet tagjai számára.

Az Iszlám Állam törökországi hálózatainak vizsgálata során megállapították, hogy különböző sejtekből tevődnek össze, tagjaik pedig nemcsak török, hanem külföldi állampolgárok is lehetnek. Az egyes sejtek a nagyvárosokban szétszórva, munkafolyamatokra specializálódva müködnek, amelyek lehetnek a terrortámadások végrehajtásáért felelös úgynevezett emni; hírszerző; logisztikai; a szír-török határral kapcsolatos feladatokat ellátó; kommunikációs vagy pénzügyi egységek. A sejtek a városokban jelen levő emír ellenőrzése alá tartoznak, aki a regionális vezetőnek (szintén emír) felel és jelent. Az egységek közül kiemelhetők az emni és a hírszerző csoportok, amelyeket közvetlenül a szíriai Rakkából irányítottak. $^{26}$

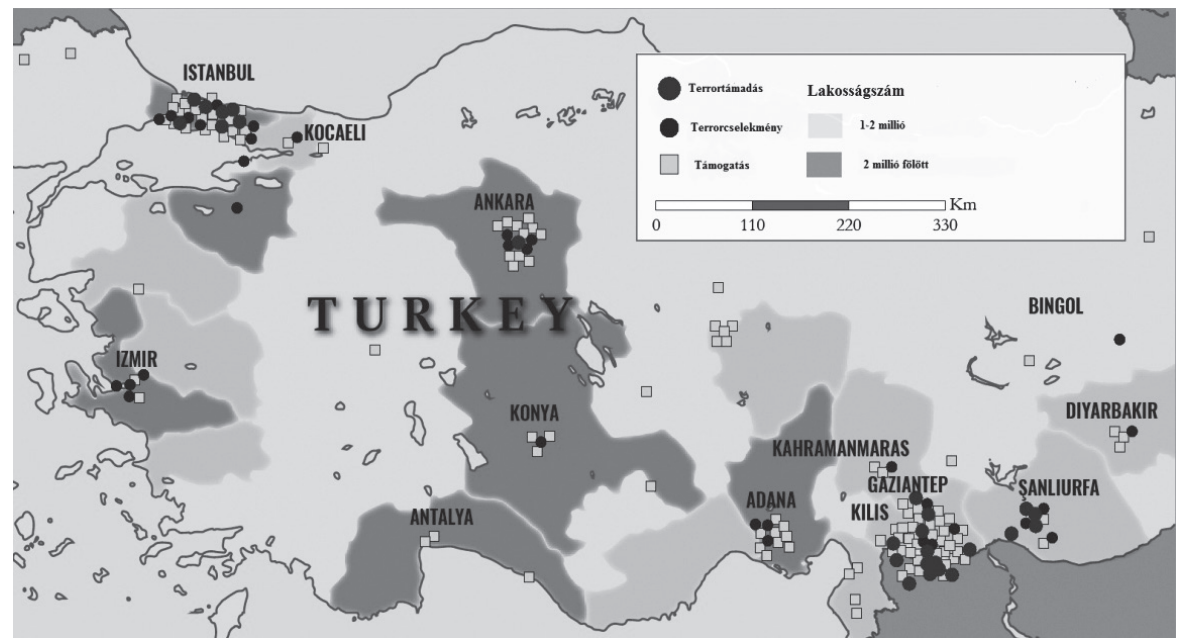

1. ábra: Az Iszlám Állam tevékenysége Törökországban (2014. június - 2017. január)

Forrás: Combating Terrorism Center at West Point [2019. 03. 11.]

A törökországi sejtek struktúrájukat tekintve alapvetően két típusúak lehetnek. Az egyik a kizárólag török nemzetiségüekből álló, kevésbé tapasztalt személyek összessége, amelyek elsősorban öngyilkos merényleteket hajthatnak végre. Erre példa a Dokumac1-hálózat, amely tagjai 2015-ben Diyarbakır településen hajtottak végre robbantásos merényletet. A másik típust az alapvetően a külföldi terrorista harcosok alkotják, akik nem „keverednek" más sejtekkel és elsősorban a Kaukázus térségéből, Dagesztánból, Csecsenföldről és Ingusföldről érkeznek, illetve a közép-ázsiai volt szovjet tagköztársaságokból származnak. Ezen harcosok számára nagy előnyt jelent, hogy azonos nyelvet beszélnek, amely segítségével könnyebb és hatékonyabb az együttmüködés. ${ }^{27}$ A Reina szórakozóhelynél, valamint a 2016. június 28-án az isztambuli repülőtérnél végrehajtott támadások előkészítésénél a kaukázusi és a közép-ázsiai külföldi harcosok kiemelt szerepet játszottak. Utóbbi

\footnotetext{
YAYLA: i. m., 12.

27 Harleen Gambhir: Isis Declares Governorate in Russia’s North Caucasus Region, [online], 2015. 06. 23. Forrás: Understandingwar.org [2019. 03. 12.]
} 
terrorcselekményt két dagesztáni nemzetiségü férfi, Rakim Bulgarov és Vadim Osmanov követte el, akik egy hónappal a merényletek előtt érkeztek az országba. ${ }^{28} \mathrm{~A}$ támadás kitervelője pedig egy csecsen nemzetiségü férfi, Akhmed Rajapovich Chatayev volt, aki az Iszlám Állam vezetőjeként 2013 és 2015 között Törökországban tartózkodott. ${ }^{29}$

Ahogy korábban a Reina-terrorcselekmény előkészítésénél kifejtettem, az Iszlám Állam tagjainak bújtatására országszerte, elsősorban a nagyvárosokban számos menedékházat alakítottak ki. Ezeket a búvóhelyeket a terrorszervezet többször használta, mind a törökországi, mind pedig a határon túli, Szíriába irányuló mozgásaik támogatására. ${ }^{30} \mathrm{~A}$ török hatóságok információi szerint az Iszlám Állam több kiképző központot tartott fent a Sincan, Altındağ, Etimesgut és Çubuk településeken, ahol török fiatalok felkészítését végezték a terrorszervezethez való csatlakozásukat megelőzően. ${ }^{31} \mathrm{Az}$ isztambuli nemzetközi repülőtéren végrehajtott terrorcselekménnyel kapcsolatban megállapítást nyert, hogy az egyik elkövető Vadim Osmanovot egy az Iszlám Államhoz köthető törökországi kiképző táborban készítették fel a merényletre. ${ }^{32}$

\section{Török válaszok az Iszlám Állam jelentette fenyegetésekre}

A fentiekben részletezett események rámutatnak arra, hogy az Iszlám Állam tehát kiépítette hálózatát az országban. A kezdetben megengedőbb fellépés az iszlamista szervezettel szemben azzal indokolható, hogy az Iszlám Állam ellenségesen lépett fel mind az Aszadkormánnyal, mind pedig a PKK-hoz köthető kurd harcosokkal szemben, amely egyben megfelelt a török külpolitikai irányoknak. A másik szempont, amely ugyancsak hatással lehetett a terrorszervezet törökországi működésére, hogy a politikai vezetés sokáig úgy vélte a PKK nagyobb fenyegetést jelent az ország számára, mint az iszlamisták. A török rendvédelem gyakorlatilag alig hajtott végre terrorelhárító müveletet 2014-ben és 2015-ben az Iszlám Állam vagy más dzsihádista terrorszervezet ellen. A helyzet 2016-ban annyival változott, hogy a hatóságok nagyobb figyelmet fordítottak ezen szervezetek müködésére, azonban elsősorban reaktív és nem proaktív, a cselekményekre reagáló és nem az elkövetést megelöző intézkedésekkel. ${ }^{33}$ A török vezetés 2016 első felében az ország területén átutazó külföldi terrorista harcosok feltartóztatásával is csak másodlagosan foglalkozott. ${ }^{34}$ Ennek következtében Törökországon keresztül több ezer dzsihádista harcos utazott át, hogy részt vegyen a Szíriában zajló konfliktusokban. ${ }^{35}$

28 Duygu Güvenç: Bombadan 10 gün geçti, açıklama yok, [online], 2016. 07. 06. Forrás: Cumhuriyet.com.tr [2019. 03. 10]

29 İşte hain saldırıdaki yılanın başı! Tek kol, [online], 2016. 07. 01. Forrás: Kibris724.com [2018. 03. 11.]

30 Reina saldırganının eşi dahil 11 kişi tutuklandı, [online], 2017. 02. 05. Forrás: Gazeteyenigun.com.tr [2019. 03. 11.]

31 İddianameden: IŞiD Ankara’da okullar açtı, çocuklara karne dağıttı, [online], 2017. 03. 03. Forrás: Gundemotuzbes.com [2019. 03. 11.]

32 Havalimanı bombacısı İstanbul'da eğitilmiş, [online], 2017. 03. 02. Forrás: Birgun.net [2019. 03. 11.]

33 Ahmet S. YaYla - Anne Speckhard: The ISIS Istanbul Reina Night Club Attack: A Lesson In What Happens When One Invites Cannibals To Dinner, [online], 2017. 01. 02. Forrás: Huffingtonpost.com [2019. 03. 18.]

34 Rukmini Callimachi: Turkey, a Conduit for Fighters Joining ISIS, Begins to Feel Its Wrath, [online], 2016. 06. 29. Forrás: Nytimes.com [2019. 03. 21.]

35 Ashley KIRK: Iraq and Syria: How many foreign fighters are fighting for ISIL? [online], 2016. 03. 24. Forrás: Telegraph. co.uk [2019. 03. 20.] 
A szíriai konfliktus eszkalálódásával menekültek tömegei érkeztek az országba, amely a korábban beszivárgó harcosok mellett további - a menekülthullámot kihasználó potenciális terroristák miatt - biztonsági kockázatot jelentett, kiemelten a határ menti települések számára. A Törökországban tartózkodó mintegy 3,6 millió szír menekültből körülbelül 1,5 millió jelenleg is a határ menti Hatay, Gaziantep, Kilis, Şanlıurfa és Mardin települések menekülttáboraiban, valamint a városok közterületein él. ${ }^{36}$

Az Iszlám Állam a rendszeresen megjelenő Rumiyah propagandakiadványának 2017. január 6-ai, ötödik számában háborút hirdetett Törökország ellen. A terrorszervezet szerint az erőszakos fellépést az ankarai kormányzat NATO-tagsága, az ország szekuláris berendezkedése, az Iszlám Âllam ellen Szíriában és Törökországban végrehajtott biztonsági és katonai intézkedései, valamint az iraki síta kormányzat politikai támogatása indokolta. ${ }^{37}$

A Reina szórakozóhelynél elkövetett terrorcselekmény utáni vizsgálatok megállapították az Iszlám Állam növekvő jelenlétét az országban, amely cselekvésre ösztönözte a török rendvédelmi szerveket. A nyomozások rávilágítottak a terrorszervezet beágyazottságára, elsősorban a nagyobb városokban, kiterjedt hálózatának működésére, támogatói és logisztikai hátterére, illetve a fenyegetés jelentőségére is. A török rendőrség és titkosszolgálatok kiemelt szempontként tekintettek arra, hogy a Reina elkövetőjét Szíriából titkosított üzenetküldő szolgáltatásokon, alkalmazásokon keresztül irányították és adtak neki utasításokat. További aggályokat vetett fel, hogy Masharipovot egy hatékonyan együttműködő hálózat segítette mind a terrorcselekmény elkövetése, mind pedig a hatóságok elöli elrejtőzése során. Ezek mind arra mutattak rá, hogy a török terrorelhárító szerveinek hatékonyabb és összehangoltabb müködésre van szüksége. Az ellenintézkedések gyors bevezetésénél azt is mérlegelni kellett, hogy a további, külföldiek által látogatott szórakozóhelyek vagy diplomáciai képviseletek, kereskedelmi központok, adott esetben turisták ellen elkövetett terrorcselekmények megnövekedésének negatív gazdasági hatásai is lehetnek. ${ }^{38}$

\section{A határbiztonság növelése az illegális migráció csökkentése és a terrorizmus megelőzése céljából}

A szíriai polgárháború során az országból kiinduló menekültválság következtében a török határvédelem kérdése egyre inkább a belpolitika és a nemzetközi politika érdeklődésének középpontjába került. Törökország jelentős, mintegy 911 km hosszú közös határszakasszal rendelkezik Szíriával. A közös határszakaszt számos természeti akadály szegélyezi, amelyek közül megtalálhatók a folyók, az erdős területek, valamint a török hadsereg által létrehozott, az átkelést megnehezítő mesterséges akadályrendszerek. Mindezek mellett azonban számos pontja volt korábban a határnak, amelyek jól járhatóak és viszonylag védtelenek voltak egy nagyobb tömeg átkelése esetén.

Az országba irányuló bevándorlást megkönnyítette, hogy a szíriai konfliktus gyors lezárásában való bizakodás miatt, valamint az ebből adódó politikai „haszonszerzéstől” vezérelve a török állam meghirdette az úgynevezett „nyitott kapuk” (açık kapı) politikáját.

\footnotetext{
36 Turkish border cities host almost half of Syrian refugees, [online], 2018. 01. 08. Forrás: Dailysabah.com [2019. 03. 19.]

37 Rumiyah Issue 5, [online], 2017. 01. 06. Forrás: Azelin.files.wordpress.com [2019. 03. 20.]

38 YAYla: i. m., 14.
} 
A lépéssel a politikai vezetés demonstrálni szerette volna, hogy Törökország elkötelezett az emberi jogok védelme mellett, és a jövőben is fontos tényezője kíván maradni a szíriai eseményeknek, majd később pedig a rendezés folyamatának.

Az Észak-Szíriára átterjedő harci események viszont egyre nehezebb helyzetbe hozták az ankarai kormányzatot, mivel a fenyegetettség során a határ menti török települések biztonsága vált veszélyeztetetté. Míg a szíriai polgárháború első éveiben az Aszad-rezsimmel alakultak ki határincidensek, 2016 elejére az ország több városában elkövetett robbantások mellett már Kilist is elérték az Iszlám Állam rakétatámadásai. ${ }^{39} \mathrm{~A}$ helyzet különösen bizonytalanná vált akkor, amikor az Iszlám Állam hatalmi központja Rakkában összpontosult és a terrorszervezet elfoglalta Moszult, amellyel geopolitikai szereplöjévé vált a régiónak. ${ }^{40}$

Az Iszlám Állam jelentette kihívások növekedése döntési kényszer elé állította a török kormányzatot, amely következtében Ankara meghirdette a „zéró tolerancia” politikáját a határbiztonság terén. A meghirdetett új irány egyben azt is jelentette, hogy a török rendvédelmi és határvédelmi egységek egyre erőteljesebben léptek fel az Iszlám Államhoz és más terrorszervezetekhez köthető külföldi terrorista harcosokkal szemben. A határvédelem megerösítése egyrészt élőerővel, másrészt fizikai eszközök alkalmazásával valósult meg, amely egy integrált politikai megközelítést követelt a határok biztonsága érdekében.

Ennek alapján a török kormány 2015-ben bejelentette, hogy a szír-török határszakasz teljes hosszában, az eddigi biztonsági akadályok mellett betonfalat, teljes határzárat kíván emelni. Az építményt három méter magasra, két méter szélesre tervezték, amelynek elemei egyenként hét tonna tömegü, mozgatható tömbökből áll, tetején pedig pengés drót húzódik, illetve örtornyokkal védik. A betonfalat áthelyezhetö elemekből építették, így szükség esetén lebonthatják és más helyen építhetik fel. ${ }^{41}$ Emellett növelték a határőrizeti erők létszámát is a térségben. A török kormány 2018. június 6-án jelentette be, hogy 764 km hosszan elkészült a török betonfal, és jelentős eredményeket tud felmutatni az irreguláris migráció, valamint a terrorizmus visszaszorításában. ${ }^{42}$

\section{A külföldi terrorista harcosok elleni küzdelem}

Törökország geopolitikai elhelyezkedésének köszönhetően az egyik tranzitországnak tekinthető a szíriai és iraki konfliktusövezetekbe utazó európai radikális személyek számára. 2011 óta az országban 9350 személyt tartóztattak le, akik a gyanú szerint külföldi terrorista harcosként részt vettek a szíriai polgárháborúban. ${ }^{43} \mathrm{~A}$ kis-ázsiai ország földrajzi elhelyezkedéséből adódóan a harcokban részt vevők búvóhelyéül és logisztikai háttérterületének is tekinthető. Mindezekből az is következhet, hogy az Iszlám Állam és a szervezethez köthető

39 EGEREsi Zoltán: Ki mit nyert? Több mint egy évvel a menekültügyi „megállapodás” után, [online], 2017. 06. 29. Forrás: Svkk.uni-nke.hu [2019. 04. 01.]

40 Murat YeşıteTAş: Neighboring a Civil War - Turkey’s Border Security with Syria, [online], 2015. 10. 01. Forrás: File.setav. org [2019. 04. 02.]

${ }_{41}$ Törökország újabb 290 kilométer falat épített a szír határra, [online], 2017. 02. 26. Forrás: Origo.hu [2019. 02. 05.]

42 Tuba ŞAHIN: Turkey installs $764 \mathrm{~km}$ security wall on Syria border, [online], 2018. 06. 09. Forrás: Aa.com.tr [2019. 03. 25.]

43 Investigation, Prosecution and Adjudication of Foreign Terrorist Fighter Cases for South and South-East Asia, [online], 2018. 06. 01. Forrás: Unodc.org [2019. 04. 01.] 
külföldi terrorista harcosok műveleti területüknek is tekintik Törökországot, amely a korábban bemutatottak szerint közvetlen fenyegetést jelent számára.

A kiutazó harcosok utazásaikat jellemzően légi és/vagy szárazföldi útvonalakon tervezték meg Törökország, Jordánia vagy Libanon közbeiktatásával. Törökország egyben kulcsfontosságú pihentető helye is a külföldi terrorista harcosoknak, jól kihasználható ugyanis a Szíriával való hosszú, nehezen ellenőrizhető határszakasza. A kiutazók gyakran utaztak Isztambulba majd onnan a hatayi vagy egy másik, a szíriai határhoz közeli repülöterekre. Gyakran charterjáratokkal próbáltak az országba belépni, amelyek úti céljai közel esnek a szír határhoz. ${ }^{44}$

Ankara érzékelve a külföldi harcosok jelentette fenyegetést, számos intézkedést vezetett be annak érdekében, hogy megállítsa, vagy legalábbis csökkentse a déli határon Szíriába beutazó radikális harcosok mozgását. Az intézkedések között szerepel a terroristákat tartalmazó ellenőrző listák (no-entry list), a Kockázatkezelési Csoportok létrehozása, amelyek a beutazó gyanús személyeket hivatottak azonosítani, de idesorolható a határ fizikai megerősítése betonfallal, amelyről korábban már esett szó, valamint a terrorcselekményekben részt vett személyek vagyonának az elkobzása is. ${ }^{45}$

A Kockázatkezelési Csoportokat 2014-ben hozták létre, és feladatuk, hogy kiszürjék a potenciális terroristákat a repülőtereken, a kikötőknél, a buszállomásoknál, illetve a határok be- és kilépési pontjainál. Az ellenőrző csoportok tagjai a gyanús személyeket a közösségi médián keresztül is monitorozzák, valamint megvizsgálják az adott személy közösségi média használati szokásait, hozzászólásait, azok szélsőséges tartalmait, illetve azt is, hogy a személy köthetö-e valamelyik radikális csoporthoz vagy terrorszervezethez. Amennyiben a gyanús személy „fennakad” az ellenőrzéseken, úgy abban az esetben a hatóságok megtagadják számára az országba való beutazást.

A külföldi terrorista harcosok országon való átutazásának megakadályozásában a török fegyveres erők is részt vesznek. Kiemelt figyelmet kapnak az embercsempészek által használt útvonalak, mivel megfigyelhető volt, hogy számos radikális személyt az embercsempészek szállították Törökországból Szíriába. A fokozott katonai jelenlét és a biztonsági intézkedések megerösítése már 2016-ban is javulást mutatott az átutazó szélsőségesek számának csökkenésében. A határvédelmi erők által alkalmazott szigorú ellenőrzések következtében megnövekedett a letartóztatottak száma a határmenti településeken és a határátkelőknél. ${ }^{46}$

Az elmúlt években a beutazó személyek gyanús pénzmozgásai is a török hatóságok figyelmének középpontjába kerültek, és szigorúbb ellenőrzéseket vezettek be a terrorizmus finanszírozása terén. A terroristák által használt pénzügyi müveletek módjai sokfélék lehetnek, amelyek között megtalálható a készpénz csempészése Szíriába; a török-szíriai határ közelében egy pénzküldési szolgáltatónak átutalt pénzösszeg felvétele, majd átcsempészése a határ szíriai oldalára; készpénz küldése futárral; a hawalarendszer ${ }^{47}$ vagy a virtuális

\footnotetext{
44 Microfinancing the Caliphate: How the Islamic State is Unlocking the Assets of European Recruits, [online], 2016.05. 01. Forrás: Ctc.usma.edu [2019. 04. 02.]

45 Imai KoHEI: Rethinking the Insulator State: Turkey's Border Security and the Syrian Civil War, [online], 2016. 01.01. Forrás: Eprints.lib.hokudai.ac.jp [2019. 04. 03.]

46 Uo., 14-21.

47 Pénzmosási technika, amely a pénzeszköz fizikai mozgása, mozgatása nélkül valósul meg.
} 
fizetőeszközök használata. ${ }^{48} \mathrm{Az}$ Iszlám Állam jelentette fenyegetések növekedésével párhuzamosan megfigyelhető volt, hogy az országban egyre több, gyanús pénzmozgáshoz köthető pénzügyi eszköz befagyasztására került sor. A felderítés munkáját ugyanakkor nehezíti, hogy egyes személyek olyan pénzügyi szolgáltatókon keresztül bonyolítják le a tranzakciókat, mint a Western Union vagy a MoneyGram, illetve számos kevésbé közismert pénzügyi szolgáltató, amelyek a török-szír határ közelében müködnek. ${ }^{49}$

\section{Következtetések}

Az Iszlám Állam elöretörése nemcsak egy önmagában értelmezhető folyamatnak tekinthető, hanem az egész közel-keleti régiót érintő átalakulás egyik elemének és következményének. A terrorszervezet létrejötte és térnyerése annak a 2010 végén indult, a térség politikai és társadalmi átalakulásának egyik állomása, amely a köztudatban „arab tavasz” néven vált ismertté. A tanulmány az Iszlám Állam „hatalmának csúcsán” a régió egyik kulcsállamában, Törökországban végbement jelenségek egy részét tekinti át, és értékeli a szervezet müködését, amely geopolitikai és geostratégiai jelentőséggel is bír.

A terrorszervezet jelenleg visszaszorulóban van Szíriában, az elemzés készítésének időpontjában a dzsihádisták elkeseredett harcot vívnak a Deir-ez-Zór tartományban lévő Baghúz település térségében, amely a szervezet müködésének egyik szakaszát, viszont egy új elindítását is eredményezheti. Kiemelt problémaként kezelendő az Iszlám Állam által képviselt eszme és ideológia terjedése és terjesztése, amely - az elmúlt évek tapasztalatai alapján - viszonylag könnyen utat tudott találni magának nemcsak a közel-keleti, de a nyugati társadalmakban is. A szervezet egyértelmü célja, hogy az iszlám egyik sajátos, erőszakos értelmezése terjedjen el, és egy „világkalifátus” alakuljon ki, amellyel geopolitikai szereplővé kíván válni. Az Iszlám Állam által képviselt felfogással szemben a más irányt magukénak valló muszlimok és szervezetek is veszélyben érezhetik magukat, amelyeket létükben is fenyegetheti a terrorszervezet.

Az Iszlám Állam hálózatának működése egyes országok és régiók esetében közvetett, mások esetében azonban közvetlen fenyegetést jelent. A kihívások sokfélék lehetnek, amelyek kezelése kizárólag az egymást kiegészítő, és a különböző eszközök integrált módon történő alkalmazásával lehet eredményes. A terrorszervezet kötelékében harcoló külföldi harcosok problematikája jelenti az egyik leginkább akut fenyegetést a nemzetközi közösség számos állama számára, igaz ez Törökország esetében is. A radikális harcosok teljes létszáma 2015 végén kb. 27-33 ezer före volt tehető, akik legalább 86 országból érkeztek. ${ }^{50}$ Ezen személyek a harci tapasztalatuk mellett, számos, egyéb erőszakos cselekmények elkövetésére irányuló képzettséget is elsajátíthattak, aminek következtében a visszatérésük komoly nemzetbiztonsági kockázatot és kihívást jelenthet a „kiinduló” országokra nézve.

Törökország a szíriai konfliktus előrehaladásával egyre inkább az Iszlám Állam müködési területévé vált, ahol erőteljes hálózatépítő és toborzó tevékenységet folytatott.

48 Például ilyen lehet a bitcoin.

49 MÁLnÁssy András: Az európai külföldi harcosok és az Iszlám Állam támogatói által használt terrorfinanszírozási módszerek, [online], 2016. 02. 01. Forrás: Epa.oszk.hu [2019. 04. 05.]

50 Thomas Hegghammer: The rise of Muslim foreign fighters, International Security, 35. évf. 2010/3, 53-94. o. 
A kis-ázsiai ország a szervezet terjeszkedésével párhuzamosan felértékelődött, a határok átjárhatósága, és a nyitott kapuk politikájának köszönhetően pedig egyenesen logisztikai bázisként is működött. A török határbiztonság növelése céljából bevezetett intézkedések következtében jelentősen csökkent a Szíria irányából a déli határszakaszt érő migrációs nyomás, és ezzel együtt a terrorgyanús személyek beutazása az országba. Ezeknek az eredményeknek a hosszú távon történő fenntartása érdekében azonban szükség esetén további fejlesztések és intézkedések végrehajtása is indokolt lehet.

\section{FELHASZNÁLT IRODALOM}

Altın, Elif: Son dakika... Reina katliamcısından şok ifadeler! Oğlunun intihar eylemcisi olmasını istemiş, [online], 2017. 02. 11. Forrás: Milliyet.com.tr [2019. 03.21.]

Altuncu, Özgür - Tiғтıкcı, Idris: Reina saldırganının evinden çıkan Türkçe not! [online], 2017. 01. 17. Forrás: Hurriyet.com.tr [2019. 03. 21.]

Arany Anett - N. Rózsa Erzsébet - Szalai Máté: Az Iszlám Állam Kalifátusa, Osiris Kiadó, Budapest, 2016

BARAnYi Tamás Péter - SzÁlKai Kinga (szerk.): Újhold - A török külpolitika útkeresése a 21. század elején, Antall József Tudásközpont, Budapest, 2016

BASARAN, Ezgi: Secular citizens of Turkey have never felt so alone, [online], 2017. 01. 03. Forrás: Washingtonpost.com [2019. 03. 18.]

CallimachI, Rukmini: Turkey, a Conduit for Fighters Joining ISIS, Begins to Feel Its Wrath, [online], 2016. 06. 29. Forrás: Nytimes.com [2019. 03. 21.]

DEAŞ’ın ,kadı'sı Ebu Cihad kod isimli Yasser Mohammed Salem Radown tutuklandı, [online], 2017. 01. 25. Forrás: Haberturk.com [2019. 03. 21.]

DEAŞ’n ,kadı'sı Yasser Mohammed Salem Radown tutuklandı, [online], 2017. 01. 25. Forrás: Cnnturk.com [2019. 03. 22.]

Egeresi Zoltán: Az AKP külpolitikájának pillérei. In: BARANYI Tamás Péter - SzÁLKaI Kinga (szerk.): Újhold - A török külpolitika útkeresése a 21. század elején, Antall József Tudásközpont, Budapest, 2016, 121-131. o.

Egeresi Zoltán: Ki mit nyert? Több mint egy évvel a menekültügyi „megállapodás” után, [online], 2017. 06. 29. Forrás: Svkk.uni-nke.hu [2019. 04. 01.]

EGERESI Zoltán: Konfliktusok az amerikai-török kapcsolatokban, [online], 2018. 02. 12., 6. o. Forrás: Svkk. uni-nke.hu [2019. 03. 18.]

Gambhir, Harleen: Isis Declares Governorate in Russia’s North Caucasus Region, [online], 2015. 06. 23. Forrás: Understandingwar.org [2019. 03. 12.]

Gerwhr, Scott - DALY, Sara: Al-Qaida: Terrorist Selection and Recruitment, [online], 2006. 01. 01. Forrás: Rand.org [2019. 02.21.]

Grimaldi, S.G. - Koru, Selim: Is the Islamic State Trying to Draw Turkey into Syria? [online], 2016. 05. 13. Forrás: Warontherocks.com [2019. 01. 19.]

Güvenç, Duygu: Bombadan 10 gün geçti, açıklama yok, [online], 2016. 07. 06. Forrás: Cumhuriyet.com.tr [2019. 03. 10.]

Havalimanı bombacısı İstanbul'da eğitilmiş, [online], 2017. 03. 02. Forrás: Birgun.net [2019. 03. 11.]

Hegghammer, Thomas: The rise of Muslim foreign fighters, International Security, 35. évf. 2010/3, 53-94. o. DOI: https://doi.org/10.1162/ISEC_a_00023

İddianameden: IŞi̇D Ankara’da okullar açtı, çocuklara karne dağıttı, [online], 2017. 03. 03. Forrás: Gundemotuzbes.com [2019. 03. 11.]

İşte hain saldırıdaki yılanın başı! Tek kol, [online], 2016. 07. 01. Forrás: Kibris724.com [2018. 03. 11.]

Investigation, Prosecution and Adjudication of Foreign Terrorist Fighter Cases for South and South-East Asia, [online], 2018. 06. 01. Forrás: Unodc.org [2019. 04. 01.] 
KIRK, Ashley: Iraq and Syria: How many foreign fighters are fighting for ISIL?, [online], 2016. 03. 24. Forrás: Telegraph.co.uk [2019. 03. 20.]

KoHeI, Imai: Rethinking the Insulator State: Turkey's Border Security and the Syrian Civil War, [online], 2016. 01. 01. Forrás: Eprints.lib.hokudai.ac.jp [2019. 04. 03.]

Lister, Charles R.: Thr Syrian Jihad. Al-Qaeda, the Islamic State and the Evolution of the Insurgency, C. Hurst \& Co., London, 2015, 97. o.

MÁLNÁssy András: Az európai külföldi harcosok és az Iszlám Állam támogatói által használt terrorfinanszírozási módszerek, [online], 2016. 02. 01. Forrás: Epa.oszk.hu [2019. 04. 05.]

Microfinancing the Caliphate: How the Islamic State is Unlocking the Assets of European Recruits, [online], 2016. 05. 01. Forrás: Ctc.usma.edu [2019. 04. 02.]

Reina saldırganı Abdulkadir Masharipov’un eşi Zarina Nurullayeva, IŞiD’in kaçırdığı oğlunun bulunmasını istedi, [online], 2017. 02. 04. Forrás: Ulusal.com.tr [2019. 03. 22.]

Reina saldırganının eşi dahil 11 kişi tutuklandı, [online], 2017. 02. 05. Forrás: Gazeteyenigun.com.tr [2019. 03. 11.]

Rumiyah Issue 5, [online], 2017. 01. 06. Forrás: Azelin.files.wordpress.com [2019. 03. 20.]

ŞAHIN, Tuba: Turkey installs $764 \mathrm{~km}$ security wall on Syria border, [online], 2018. 06. 09. Forrás: Aa.com.tr [2019. 03. 25.]

Sönmez, Göktuğ: Reina Saldırısı, Maşaripov ve Orta Asyada Radikalleşme, [online], 2017. 01. 01. Forrás: Orsam.org.tr [2019. 01.20.]

STEIN, Aaron: Islamic State Network in Turkey, Recruitment for the Caliphate, [online], 2016. 10. 01. Forrás: Atlanticcouncil.org [2019.03. 10.]

Tahiroglu, Merve - Schanzer, Jonathan: Islamic State Networks in Turkey, [online], 2017. 03. 29. Forrás: Fdd.org [2019. 03. 15.]

The Jihadi Threat: ISIS, Al Qaeda and Beyond, [online], 2016. 12. 12. Forrás: Usip.org [2019. 04. 04.]

Törökország újabb 290 kilométer falat épített a szír határra, [online], 2017. 02. 26. Forrás: Origo.hu [2019. 02. 05.]

Turkish border cities host almost half of Syrian refugees, [online], 2018. 01. 08. Forrás: Dailysabah.com [2019. 03. 19.]

YAYla, Ahmet S.: The Reina Nightclub Attack and the Islamic State Threat to Turkey, [online] 2017. 03. 01. Forrás: Ctc.usma.edu [2019. 03. 20.]

YAYla, Ahmet S. - SpeckHARD, Anne: The ISIS Istanbul Reina Night Club Attack: A Lesson In What Happens When One Invites Cannibals To Dinner, [online], 2017. 01. 02. Forrás: Huffingtonpost.com [2019. 03. 18.]

YeşıLtaş, Murat: Neighboring a Civil War - Turkey’s Border Security with Syria, [online], 2015. 10. 01. Forrás: File.setav.org [2019. 04. 02.] 